\title{
Analysis of Women Representatives in Panchayati Raj Institution in Sikkim
}

\author{
Ushnata Priya Thapa \\ PhD Research Scholar, Department of Sociology, Sikkim University, 5th Mile, Tadong, Gangtok
}

*Corresponding author: Ushnata Priya Thapa;

Received 26 February 2019;

Accepted 16 March 2019;

Published 31 March 2019

\begin{abstract}
No one can doubt that the last half century has seen a marked change in the character of our society where women have gained immense position in Panchayati Raj Institution (PRI). The State of Sikkim has always welcomed various strategies for women empowerment. Empowering women through decentralisation and $73^{\text {rd }}$ Constitutional Amendment Act is effective and crucial indicator that leads good governance and promotes equality in political system which is taken to be good thing. The present paper is an attempt to locate the study in an empirical situation to analyse the experiences of women representative in Panchayati Raj Institution in Sikkim. The study examines the factors of motivation to get into politics, and with the changing role situation what kinds of problems the Panchayat Representative faces in everyday life.
\end{abstract}

Keywords: Empowerment, Governance, Decentralisation.

\section{Introduction}

To get the democratic process started in any country, women should not be left behind in the process in decision making. The concept of democracy will only assume dynamic significance when political parties and national legislature are decided jointly by men and women in equitable regard for their interest and aptitude of both halves of the population (Centre for Legislative Research and Advocacy 2008:01). In India, to find the privilege place for women, one can find equity in respect of political franchise, as they did not have to struggle. The Constitution of India, after independence, showered favor by immediately deliberating women by granting women the political rights by legitimizing their roles in participating in public life within the formal and legal framework (Devi and Laxmi 2005:14). Despite of the constitutional provision of the gender equality, only few women have been able to make a space for themselves in the institution of democratic politics. The patriarchal culture, gender based hierarchy is still dominating women by confining them with limited sphere of opportunities to represent them in political system (Narayan and Laxmi 2011:39).

However, when the model of social change diluted the structure of political system, this stipulated the growing demand for a greater decentralisation at the centre in Indian politics in the 1990s. Thus, to penetrate the issue it led to fragment the power of authority into decentralisation in the form of local self-government under the control of State government. Rationally decentralisation makes government's policy more transparent and foster more accountability at the grass root level (Crook and Manor 2000:79). The $73^{\text {rd }}$ Amendment Act of the constitution of India was a watershed in the history of decentralised governance, planning and development. This marked the emerging demand of women's group for greater visibility for women in politics. In the realm to facilitate the real empowerment, Panchayati Raj has attracted women to politic in large numbers, bringing effective changes in women's life in respect of empowering them in social, political and economic well being (Sinha 2012:30).Thus, the concept of empowering women through decentralisation in the form of Panchayati Raj Institution was made mandatory for building a nation into inclusive democracy.

\section{Conception of Panchayati Raj Institution (PRI)}

Panchayti system existed in India since time immemorial. Panchayat means a council of five members, which is seen as traditional institutions and referred to as Pancha Parmeshwar (member as God) with expectations of fairness and justice in their role of settlement of local interpersonal and community dispute (Buch 2010:5). In the traditional Indian society, when the council of five, Panchayat spoke as one, it was said to be the voice of god, and gave expression to the consensus of the traditional moral order and were acquired and legitimized by religion. The idea was generally to implicate the conflict management in both politics and laws which tends to stress arbitration, compromise and deemphasis of overt clashes, of victories and defeats (Rudolph \&Rudolph 1976:34)

During the Ancient and Medieval period, it mentions that the characteristic of the Panchayats was to serve the bridge between the agrarian village economies and high authorities in the system of self governing village community (Committee on Empowerment of Women COEOW 2010:7). Sir Charles Metcalfe characterised them as, small republic having nearly everything that they want within themselves and almost independent of any foreign relations (Aslam: 2000:56).To cite further, Mahatma Gandhi's conception 
enforce him to believe that the development of India is possible only through its indigenous political system.

These conceptions have influence post independence policies, by providing some of the rationale and legitimation for the economic and political decentralisation (Rudolph and Rudolph 1976:63). However, two milestones in the evolution of Panchayati Raj System were the B.R. Mehta Committee in 1957 it was appointed to examine the working of community development program 1952. The committee submitted the report and established the scheme of 'democratic decentralisation' which finally came to be known as Panchayat Raj. Recommending the three- tier Panchayati Raj system giving reasonable substance and content in terms of power and authority and suggested that an agency should be set up at the village level that should represent the interest and development of the village community in holistic spheres (Mohanty 1995: 3346). This was reiterated in 1977, by Ashok Mehta Committee which recommended the three tier system of Panchayat Raj to be replaced by two tier system. It also included two women in panchayat who were interested in working among women and children (Buch 2010:6). The $73^{\text {rd }}$ Amendment Act in 1993 paved the greater women forces, by reserving one- third of the total number of seats for women (Jayal 2006:19). The constitutional recognition to the Panchayat Raj body finds its expression on article 40 of the Indian constitution where it stated, "The state shall take steps to organise village Panchayats and endow them with such powers and authority as may be necessary to enable them to function as unit of self government" (Sinha and Zorena 2012:29).

The bodies of Panchayati Raj institution are legally local government and have a pyramidal structure. At the base is the Gram Sabha which elects the local government and charges it with specific responsibilities which is expected to meet at specific time, above this basic unit of democracy is Gram Panchayat (GP) which is the first level elected body covering with the population of 5,000 people this may demarcate more than one villages. At the district level is a Zilla Panchayat which is the link with the state government. In this system GP has to play a crucial role in ensuring downward accountability, transparency and voice to people (Vyasulu and Vyasulu 1999:3677-78).

\section{Analysis of Panchayat Women Representatives: Taking account in the Indian context}

In India's populist politics, largely the practice of political empowerment of women is constricted into relatively manageable areas by reservation of women within the Panchayati Raj (Baltiwala 2007: 557).However, various literatures have been analysed and reviewed considering the experiences of women in Panchayati Raj.

A study by Santha (1999) revealed that the quality of performance of the elected women representatives largely depend upon the social factors like education, literacy etc. In 1996, Kerala has the positive impact in account to empowerment of women, followed by Tamil Nadu, The study of Athreya and Rajeshevari (1998:128) finds that in the districts of Puddukottai and Thiruvallu in Tamil Nadu, 72 percent of the respondent had contested mainly because of the reservation of seats and the newly elected women representatives had attended all the meetings with fair degree of regularity. While in Haryana it is not encouraging. In this context,
(Marg 1997:75) cites that though women reflect their new visibility and impact but were handicapped by lack of literacy and powerlessness from male domination.

In Madhya Pradesh, Rajasthan and Tamil Nadu, the study of Buch (2000:19) found that women representative belonging to other backward communities occupies a highest percent and approximately 70 percent were below the age of 45 years. The young women in Panchayat mark significant. In fact, Karnataka was the first state to lower the age bar to 18 years to contest election. However, According to Mathew, as a result more of them were inexperienced in politics, since they entered in the younger age (Mohanty 1995:3349).

No doubt the women in Panchayat has gained centre of attraction, but the pattern of dignity they maintain varies within the district or block of the States. The studiesin the Ahmednagar district of Maharastra that in Relegoan village the gender disparity of creditable factor in working patterns is vivid. Whereas, at Vitner village in the Jalgoan district, women leadership has taken place and have moved towards the development priorities of the village collaborating with Non-Governmental Organisation. For instance, the incidence of alcoholism has also decline and the facility of drinking water was also available through taps. In West Bengal, Kultikri Gram Panchayat, the performance of women representatives in tribal and schedule caste population in the sphere of welfare of the village community is rated as satisfactory (Mohanty 1995:3349).

However, there has been a mixed review between the participation and representation. Mathew discussed on the article by Manu Bhaskar on women panchayat member in Kerala that based on Bhaskar's findings, the concept of empowerment does not benefit the women panchayat in terms of economic earnings of their own, only 3 per cent of the women have some occupation hence majority of the women Panchayat are economically dependent on their husband/ father (Mathew 1997:1362). The study in Vidisha and Seoni district of Madhya Pradesh found that the representations of women in PRIs are for name sake only. The works related to the PRIs are used to be done by the males either the husband, father's or brothers of women Sarpanchs. Nearly 77 per cent of the respondents accepted the fact that there has been no effective participation of women in PRIs' (Mishra and Pal 1996:91).Nevertheless, Tiwari (2009: 25) examined the women experiencing in PRIs and argued that women are gradually learning to adjust the new political conditions. Their political knowledge are increasing and gradually being installed with a sense of confidence as they became aware of the problems beings faced by the localities.

However, it is essential to note down the most important issue concern that is the difference between representation and participation. It is rather easy to Legislate representation, but creating a condition for participation is a complex and difficult task. Proper representation does not automatically lead to proper participation .Effective participation would require not only physical presence but also articulation, joining discussion, taking up issues and problems of the constituencies and efforts for solving problems and getting results wherein the representatives are expected to work for their constituents (Buch 2010:74). The doubts have been repeatedly expressed about the eligibility of women to participate in panchayat, sweeping statements are made about women being a mere figure as proxies (Pinto and Reifeld 2001:18; 
Buch 2010:74). The early exploratory studies in the state like Haryana, Madhya Pradesh, Orissa and Tamil Nadu on the observation of women's non-participation concluded that most of them did not even concede any scope for learning phase for a group which had remained politically marginalized. Relying on this observation it caused substantial damage in making assessment of women's new experience in this public sphere. The patriarchal resistance to women's new role and the preference of officials to deal with men constituted another major problem in this respect (Buch 2010:74-5). The values of patriarchal and feudal ethos constrain women for participating in politics. The reservation itself has failed to break the dominance of men over women (Santha 1999:97).

\section{Rationale of the study}

The Government's vision and perspective for the upliftment of women's welfare in terms of reservation of seats to increase female representative in Panchayat is appreciable. But the Indian Government approaches are based on quantitative analysis. Furthermore, much discussions and debates revolves around reservations, beneficiary schemes etc. Whereas, the nuance of narrative factors about their experiences on being a representative within their constituency is largely overshadowed. The State of Sikkim after merging with the Indian Union followed the democratic set up. It has been observed that a regional party and the personal charisma of the certain leader dominate the Sikkim politics. This takes an account to the Amendment Act 1997 that facilitates the participation of political party openly in the Panchayat Election by deleting the Section 127 of 1993 Act. The intense review of literature found that there have not been deep research studies in women representative's nuances of experiences and expression of their everyday life in Sikkim. The challenging aspect which the study tries to attempt is to understand how political power has influence them and have brought changes in their socio-economic and political status.

\section{Technique of the Study}

The study intends to focus on the experiences of women representatives, which depend substantially on the local sociopolitical context within Sikkim. Especially the lowest level of Panchayat Raj namely the Gram Panchayatis taken into consideration. The study area is in East District of Sikkim, five block were selected namely Pakyong, Ranka, Martam, Duga and
Gangtok which are taken for doing field work. Using a snowball method of sampling, an exclusive interview schedule was used to collect data from the 40 elected women representatives serving their term from the year 2012-2017 who are Members, Vice President and President of Gram Panchayat.

\section{Sikkim Panchayati Raj}

The Panchayat system is not new in Sikkimese society. It has been in existence from the very old days. But the emergence of Panchayati Raj in Sikkim can be trace back to the Sikkim Durbar Act of 1965. For the first time this Act established the formal single tier Panchayat, as block panchayat at the village level. The creation of block Panchayat resulted into the amalgamation of some of the old village council like Chhoddu System of Dzongu (Chettri 2008:40).This act stipulated for a non- hierarchical system and continued till 1981. Later, the Government of Sikkim removed Block Panchayat enacting the Panchayat Act 1982 and introduced two tier panchayat systems with the Gram Panchayat at the block level and Zilla Panchayats at the district level holding the importance on the basis of universal adult franchise which is followed in the present date as well (Lama 1994).This Act describe as a radical step as it aimed at promoting and developing the Panchayati Raj System as an instrument of local self government (Chettri 2008:44).The state of Sikkim is thus divided into four Zillas or Districts. In the North district i.e. in Lachen and Lachung the traditional institutions of local self government known as Dzumsas have been allowed to continue their traditional powers and are deemed to be Gram Panchayat unit for the purpose of the Sikkim Gram Panchayat Act, 1993 (Dafflon 2011:10).In Sikkim Panchayat Act 1993, it incorporated all the mandatory provision of the $73^{\text {rd }}$ Amendment Act. Election in Sikkim under the 1993 Act was conducted first time in 1997.Election to present day Panchayat was held on 29 October 2017.The women Panchayat in Sikkim is accounted parallel to male counterpart. This is depicted by the Sikkim Panchayat Amendment Act 2007. This act increases the percentage of women in local body from 33 to 50 percent. Such reservation of quota has also been provided to Limboo and Tamang communities who have already been accorded the status of Schedule tribe (Tiwari 2009:23-25; Chettri 2018:79). At present there are 113 Territorial Constituencies and 176 Gram Panchayat Units comprising of 987 wards. Following data depicts the profile of Gram Panchayat in Sikkim held on 2012 Election. This shows the equal representation of women which are 493 of elected women against 987.

Table No 01

\begin{tabular}{|c|c|c|c|c|c|c|c|c|c|c|c|c|}
\hline District & $\mathbf{S C}(\mathbf{W})$ & $\mathbf{S C}$ & $\mathbf{S T}(\mathbf{W})$ & $\mathbf{S T}$ & $\mathbf{M B C}(\mathbf{W})$ & $\mathbf{M B C}$ & $\mathbf{O B C}(\mathbf{W})$ & $\mathbf{O B C}$ & $\mathbf{U R}(\mathbf{W})$ & UR & Total & Total $(\mathbf{W R})$ \\
\hline WEST & 9 & 10 & 73 & 73 & 42 & 41 & 31 & 30 & 4 & 4 & 317 & 159 \\
\hline SOUTH & 8 & 9 & 38 & 38 & 52 & 51 & 34 & 34 & 3 & 4 & 271 & 135 \\
\hline EAST & 10 & 10 & 48 & 48 & 31 & 32 & 52 & 51 & 4 & 4 & 290 & 145 \\
\hline NORTH & 1 & - & 48 & 47 & - & 1 & - & - & 5 & 7 & 109 & 54 \\
\hline TOTAL & 28 & 29 & 207 & 206 & 125 & 125 & 117 & 115 & 16 & 19 & $* 987$ & 493 \\
\hline
\end{tabular}

*Dzumsa (Lachen and Lachung), North Sikkim = 2 Pipons, $W=$ women

Source: (Rural Management and Development Department; Government of Sikkim, RMDD; GoS).

As the analysis from the above tables indicates women in Panchayat have generated enough enthusiasm and have marked the beginning in establishing their position. However, it is important to study their behavior and process of participation in the PRI. Therefore, how they handle their identity in politics by sharing their personal experiences is beenanalyse on the basis of field work taking the sample population of 40 respondents who are the key informant and elected women representatives conducted in the East district in Sikkim.

\author{
Brief profile of the Elected Women \\ Representatives (EWRs)
}


In the present study, the profile of the EWRs in terms of age, education, marital status and religious belief is diverse. In terms of age, the data from the field reveals that 55 per cent of the Respondents i.e. a sizeable majority of the sample are found to be young and in the reproductive age group i.e. below 40 years. Few of them were the age group of above 50 years.

In terms of educational qualification, large majority of the elected women representatives were educated below higher secondary level. The reason for this, they cited, is primarily due to lack of consciousness and awareness regarding the benefits and utility of education. They also said that they were burdened with household activities, gradually making them lose interest in gaining education. However, 9 of the respondents who were between the ages of 20-30 years old are found to be graduates and postgraduates.

In the context of marital status, 50 percent of the respondents were married. On further enquiry majority of them reported that they were housewives. The unmarried respondents were 45 percent, predominantly in the age group between 20 to 30 years; they narrated to serve and hold a figure in society and thought to get married in the later stage. The remaining are widows and case of divorce was found to be absent.

The major ethnic groups present in Sikkim are Lepcha, Bhutia and Nepali. These ethnic groups can be categorized on the basis of religious affinity such as Bhutias and Lepchas practice Buddhism and majority of the Nepalese follow Hinduism and a very small sizeable portion of these ethnic groups profess Christianity. The data reveals that 47.5 percent of the total respondents practice Hinduism. Buddhism is practiced by 35 percent and the number of Christian respondents is only 17.5 percent which is the lowest in the total sample population. As per, elected women representing their community is diverse, since they have been elected on the basis of reservation criteria which follows the policy of equal distribution on the basis of caste to be reserved for them.

\section{Moderating factors and experiences of EWRs}

The study instigate by analysing the factors and experiences of women being in Panchayat. The reservation system for women in Panchayat, have been a bench mark for bringing them in a front line of public and political sphere. Such as, most of the respondents turn out to be uncontested candidates, from the constituencies reserved for women who are setting an example so that other common women also get inspired and come forward in future. For this matter, it was found that there were no male members contesting against them. However, there are many other social factors which is attached and carried within, when an individual woman becomes representative of a constituency.

The study found that majority of the women that is 72.5 percent, was first-time candidates in Panchayats, who were in between the age group of 25-35 years, mostly unmarried or recently married.Only 27.5 percent of the respondents were between the ages of 40-55 years holdingtheir second term as women representatives. As reported by the respondents, their family members were the constant support. For instance, the family members' would do the household chore so that they could do their duties and attend meetings citing regular and fair in attendance. 'However, one respondent stated that her father-in law was not happy of her joining politics as he too was Ex-Panchayat. He told her that the public may put in several demands which may not be able to fulfill at once and people are likely to make criticism. Though he expressed his feelings of not being happy with daughter in law, but did not oppose her from contesting elections.' On this account, it reported that only 30 per cent of the respondent's family member's had their relation in politics.

The major moderating factors of the women representative being captivated to be into Panchayat, as reported by the respondent was the institution of regional political system in Sikkim who is ruling the Government of Sikkim. Especially the enthralling speeches delivered by the Chief Minister Pawan Kumar Chamling have served as motivation and encouragement to these women. One of the respondents said that, for women to get involve into politics and to take the stand out of it is very essential. By doing so it changes the perception of thinking towards society. Most of the women were affiliated to ruling political parties as the members and few were the president of Challi Morcha (Women's Association) before becoming EWRs. They were given opportunity to contest the Panchayat Election by excelling their performance as party worker in regional ruling party.

On the other hand, 72.55 percent highlighted the individual selfinterest to be in Panchayat. At the same time one- fourth of the respondents were the members of social groups like Self- Help Groups (SHG), Accredited Social Health Activist (ASHA). While being members in these social groups, they got the opportunities to broaden the level of interaction to approach for official work and financial assistance provided by the government in terms of loans and assistance. This gradually made them a respected public figure and gained the confidence backed by the community to contest.

Further, 35 percent of the women representatives positively reported for the aspiration to contest in future elections and if given opportunity they aspire to contest in higher level positions like Member of Legislative Assembly. At the same time, 25 percent of elderly group of age did not choose to contest for future election. Of which they narrated their health issues and also wanted to give chance to other women so that they could also contribute for the community development. However, the other segment of the respondents was not confident to give an answer and minor segment of the respondents showed undesired interest to hold the position.

\section{Coping up with the Changing Role Situations of EWRs}

Journey from common women to elected women representatives in Panchayat is not always easy. Gaining a trust from the community, delivering speeches, opposing any decision which is not beneficial for the community development and being recognize by their own name instead of husband's name even in areas outside their jurisdiction which holds a sense of identity have become pride for the respondents. However, the respondents narrated that coping with family relations and exercising the power with official responsibilities, sometimes becomes difficult and believed that to be overburden with multiple responsibilities. The salary and perks they receive from the government were not sufficient and most of the amount is spent on transportation in attending meetings. Since the president, vice-president and members of the Panchayat receive Rs 2400, Rs 2000 and Rs 1600 per month respectively. 
Since the Panchayats have to be neutral to both the parties which requires lots of patience to handle the situations. One of the difficulties cited by the respondents who were between the ages of 25-35 years, were solving the dispute among villagers. Often the village elders do not involve young Panchayat women even though one of their duties is to settle disputes and impart equal justice.

Further, the respondents reported training to be inefficient since it imparts only for 5 days which becomes impossible to grab the knowledge of the entire system. The Panchayat representatives are expected to effectively implement the development schemes but in some cases the department do not have adequate fund at the given time in order to carry out the schemes or either the official personnel are not co-operative for giving the facilities to the public. This is then reciprocated by public being unsatisfied. Despite having various limitations elected representatives are expected to deliver and bring development to the community.

\section{Conclusion}

It is generally believed that the women in Sikkim enjoy relatively better position than their counterparts in other States of India. In respect of women representatives and their initiatives in Panchayati Raj, Sikkim is among the small States in India which is regarded as one of the best performing States (Chettri 2008:208). In this context, it cannot be denied by the study which revealed that through the policy of reservation women has made a significant beginning as they stated, if the seats were not reserved for women, they would not have been able to contest at all. Entry in the Panchayat has given them the ability to re-examine their lives, came to know about power relations and structure of the functioning of the government. The women representatives devoted time to Panchayat work, taking joint decision and responsibilities' with the other Panchayat members in any important issues, they participated in the meetings and listen patiently and addressed the issues raised by the public which is commendable. This shows that a large number of women are effectively participating, making decisions and taking responsibilities in Panchayat activities. At the same time the study revealed the unpleasantness with the amount of salary they get which is difficult for them to sustain.

Since, majority of the women representatives was self-interested to be a part of political institution and did not come from the political family background. However, middle class women were found to take the advantage of Panchayat entitlement. The analysis of the data reveals that they have perceive themselves to acquire selfesteem from their present work as representatives which are the maker of empowerment process and were willing to contest for the next elections.

The study brought out that the women need to enhance their capacity not merely to enter into Panchayat and carry out Panchayat functions but more importantly to manage politics and responsibility for the village community. The increase in the number of women representatives in the political institution not only leads to their inclusion in the government activities but also reflects the changes towards the betterment in their socio-economic status. In this regard, political party should not be instrumental but rather should focus on women quality and performance in terms of contesting from the respective political party. Whilst, the study found the immense support from the family and community members, which is and should be, valuable so that the women
Panchayat can be motivated to play the greater role for the betterment of society and enhance their interest, executing with positive action.

\section{References}

[1] Aslam, M. (2007). Panchayati Raj in India. New Delhi: National Book Trust of India.

[2] Athreya, V.B and Rajeshevari, K.S. (1998). Women's Participation in Panchayati Raj: A case study from Tamil Nadu. M.S. Swaminathan Foundation.

[3] Baltiwala, S. (2007). Taking the Power out of Empowerment: An Experimental Account. Development in Practice: Vol.17, No. 4/5. pp 557-565.

[4] Butch, N. (2000). Panchayat and Women. In George Mathew (Eds.), status of panchayati Rai in the states and union territories of India, institute of social science. New Delhi: Concept publishing company.

[5] Women and Panchayats in India: From Oppression to Assertion. New Delhi: Routledge Taylor and Francis Group.

[6] Chettri, H. (2008). Panchayati Raj System and Developing Planning. New Delhi: Rawat Publication.

[7] Centre for Legislative Research and Advocacy. (2008). Women's Reservation: A long Delayed and a Much Needed Step. CLRA: Policy Brief for Parliamentarians: Policy brief Series no: 3; pp 1-8.

[8] Devi D, Syamala and Lakshmi, G. (2005).Political Empowerment of Women in Indian Legislature: A Study; The Indian of Political Science, Indian Political Science Association: Vol.66, No.1; pp 75-92.

[9] Jayal, N. G. (2006).Endangering Local Democracy: The impact for quotas for women in India's Panchayats Democratization. Vol.13, No.1; pp, 15-35.

[10] Lama, M.P. (Eds) (1994). Sikkim Society Polity Economy Environment New Delhi: Indus Publishing Company.

[11] Mathew, P.M. (1997).Women in Panchayat: The More Relevant Questions. Economic and Political Weekly. Vol. 32, No.23; pp.1362-1362.

[12] Mohanty, B. (1995).Panchayati Raj, 73rd Constitutional Amendment and Women. Economy and Political Weekly. Vol. 30, No.52; pp 3346-3350.

[13] Narayan, E.A and Lakshmi, E.V.(2011). Women development in India. New Delhi: Regal Publication.

[14] Rudolph, S and Hoeba, r R. (1976). Gandhi: the traditional roots of charisma. Chicago and London. The University of Chicago Press.

[15] Sinha, A.C. (2008). Sikkim Feudal and Democratic. New Delhi: Indus Publishing Company.

[16] Sinha, H and Zorena, J. (2012). (Eds). Empowerment of Women in North- East India: Socio-economic Perspective. New Delhi. Concept Publishing.

[17] Santha, E.K. (1996). Political Participation of Women in Panchayat Raj. ISS; Occasional Paper.

[18] Tiwari, N. (2009).Rethinking the Rotation Term in Panchayats. Economic and Political Weekly. Vol.44, No.5: pp 23-25.

[19] Vysaulu, P and Vysaulu, V. (1999). Women in Panchayati Raj: Grassroots Democracy in Malgudi. Economic and Political Weekly: Vol.34, No. 52; pp 3677-3686. 